\title{
A Polish-Canadian Trajectory of Feelings
}

Arlette Cousture, Dzieci stamtąd. Nawet ptaki umilkły, Kraków: WAM 2017 , pp. 568.

A Polish-Canadian literary mosaic Dzieci stamtad. Nawet ptaki umilkły (Children From There. Even The Birds Turned Silent), in French original: Ces Enfants d'ailleurs. Même les oiseaux se sont tus), written by Arlette Cousture - reached Polish readers over twenty years after its premiere on the French-Canadian book market. Its publication in Polish (Dzieci stamtąd. Nawet ptaki umilkły, 2017²) coincided with a double jubilee - the $150^{\text {th }}$ birthday of the Confederation of Canada and the $75^{\text {th }}$ anniversary of diplomatic relations between Poland and Canada. The first volume of this family saga, divided into six parts, was translated from French into Polish by three women: Iwona Badowska (parts 1-2), Grażyna Majcher (parts 3-4) and Katarzyna Chojnowska (parts 5-6). It was a courageous 'joint venture' which perhaps carried the risk that the Polish text would become a work written in three different literary styles.

Polish readers know very little about French-Canadian literature. Most of us would probably be unable to respond when asked to name even a single French-Canadian writer. Thus, learning that the history of the immigration of Polish people to Canada has been a source of literary inspiration for a bestselling author in French Canada comes as a pleasant surprise.

\footnotetext{
1 Contact: justyna.budzik@uj.edu.pl

2 A. Cousture (2017), Dzieci stamtąd. Nawet ptaki umilkły, I. Badowska, G. Majcher, K. Chojnowska, (trans.) Kraków: Wydawnictwo WAM, 2017. 
Arlette Cousture is a very prolific writer; her literary output includes novels, novellas, stories, essays and dramas. She has been awarded on several occasions for her literary achievements and is well-respected for her involvement in raising public awareness of multiple sclerosis (from which she suffers), as well as challenges faced by handicapped children. Immensely popular in francophone Canada, Cousture stole the hearts of her readers with her three-volume novel The Daughters of Caleb (Les filles de Caleb), which conquered the French-Canadian book market in the 1980s (the last volume was released in 2004). The author captivated her readers by addressing the most popular themes in Québec's literature at the time, namely: the characteristics of life in rural Québec and the changing image of women in this part of Canada. Last but not least, she also shed new light on le roman de la terre. The book's success led to it being made into a TV series which received an extremely warm reception not only in French Canada, but also in Poland, where it was broadcast in $1995^{3}$.

The author visited Poland in the fall of 2017 to promote Dzieci stamtad during Krakow's Book Fair. I went there with the intention of buying Diderot's essays on art and some books about the history of migration from Europe to North America. I was completely unaware that I could also buy a publication which parallels my interests and showcases the problem of migrating Europeans, Poles in particular, by presenting it in a semi-fictional manner. Several months later, I started to read Dzieci stamtad. I knew almost nothing about the book's plot, and had not heard anything about it that would particularly fuel my enthusiasm to read it. To be perfectly honest, family saga is not my favourite literary genre. The book's front cover did not seem encouraging either. Małgorzata Kożuchowska - not a renowned literary critic, but rather a TV series starlet - was quoted as saying that Dzieci stamtad is a novel about how Polishness can be so deeply-rooted in people that it remains unscathed in them even after living far away from their motherland for many years.

The story begins in 1939 in war-torn Krakow, where the Pawulski family lives. Tomasz (Thomas) and Zofia (Sophie) Pawulski and their children - Jerzy (George), Elżbieta (Elizabeth), Jan (John) and Adam - represent the Polish intelligentsia. Thomas is a history professor at the Jagiellonian University, and his wife is a musician and music teacher. Their offspring are raised to obey moral and ethical standards and to pay due respect to their intellectual development. The war shatters their dreams of living happily and inseparably. George, against the will of his parents, enlists in the army, while Thomas, Sophie and Adam are killed by the Germans. By pure luck, Elizabeth and John escape alive. Scared to death, they hide in the tenement house where they have lived so far, and witness the shooting of their parents. Fortunately, their presence there goes unnoticed. Having decided to flee Poland, they take with them the memory of their loved ones, as well as a few

${ }^{3}$ Filmweb, Le Fills de Caleb, https://www.filmweb.pl/serial/Les+Filles+de+Caleb-1990-131045. [Accessed 20.02.2018]. 
things of sentimental value - their father's glasses, their mother's violin case and a handful of Polish soil. Elizabeth and John flee Poland without any hope that they will ever see their oldest brother George again. They are all miraculously reunited in Canada several years later. The siblings desperately try to start a new life there, and they partially succeed with the help of other immigrants of Polish descent as well as the family's spiritual leader - a French-Canadian priest named Villeneuve, an old friend of the Pawulski family. This family saga runs from 1939 to 1952 and, in geographical terms, between two provinces - Manitoba, where George lives with his wife Ann and their child, and Québec, the place chosen by John and Elizabeth. The reunited family will be put to the test again, but this time the pain that ensues will be self-inflicted.

Those who enjoy family sagas will probably read this book with bated breath, as the novel is very engrossing in the way it showcases a whole constellation of emotions and the twists and turns in the family's history. Cousture excels in truly moving descriptions, for instance when she describes the killing of the Pawulskis and the subsequent reaction of their children left alone in the street, totally stunned, looking helplessly at a spot of blood and their father's glasses. The novel is filled with such descriptions and emotional scenes, as well as powerful dialogue.

A typical historical novel it is not, but the story's background is composed of significant historical facts gracefully fused with the fictitious ones. The author of The Daughters of Caleb, with the help of her husband, did extensive research which encompassed the history of Poland during the interwar period and the Second World War, the conditions in which immigrants to Canada lived and the reception they received there in the 1940s and 1950s. They also studied historical texts about the establishment of Polish parishes in Canada and priests from Western Canada who travelled to Poland in the interwar period. But above all, it is Arlette Cousture's father to whom she owes the first-hand experience of living in the context' of various immigrant stories. He professionally helped immigrants in Canada, first when he worked for Canadian National Railway Company, then for the Association for Catholic Immigrants, and finally in the 1960s, when he set up the Ministry of Immigration in Québec. She was taught respect for people of different nationalities, whom the Canadian authorities called New Canadians. These facts must have influenced her sensitivity to people's life stories to a great extent. It is, however, not enough to employ one's respect, sensitivity and thematic knowledge in order to provide an interesting and convincing literary account about a chosen immigrant group which settled in a foreign land. It is equally important to capture something much more elusive, in this case - the Polish genius loci typical of the given period to which the author refers, and also a universal one that goes beyond time and place. It seems that Arlette Cousture has partially accomplished this goal, but unfortunately rather than delving beneath the surface of the Krakovian genius loci of the 1940s, she resorted to a simplified version of it. The spirit of the 
time and place is created here by Krakow's most typical emblem - the bugle call from Saint Mary's Basilica. We read about it when the Pawulski family are still in Krakow and later in the following parts of the saga, when the main characters recall it.

The place in its geographical dimension is of deep significance in the novel, as it defines its main characters and is connected to their sense of (non)belonging. Yet, it is hard to escape the feeling that the topography of the Polish and Canadian space has been limited mainly and literally to the interiors in which the Pawulskis stay at a given time. As far as Poland is concerned, we learn about the setting from the perspective of the Pawulskis' flat, and not much is said about the city or its character, as if the only anchors of this place were the bugle call and Wawel Castle. The same concerns Canadian space. We travel to Manitoba and Québec with the Pawulskis but our knowledge about these places is very limited. The reader's imagination moves between the rooms where the plot is set, a shop owned by a Polish man named Mr. Favreau (who changed his Polish name to Favreau when he settled in Canada) where John works, and the flats of the people whose children Elizabeth teaches violin. It is understandable, of course, that the author wanted to concentrate on the trajectory of emotions and feelings and focused primarily on family relationships, but it is a pity that Cousture resigned from presenting in more detail the cultural and social tone of both places - Poland and Canada.

I must admit that I also found it quite difficult to get through the thicket of over-emotional dialogues and descriptions which, as I have already noted, will probably please fans of family sagas. For those who are less enthusiastic when it comes to such works, the emotional and sentimental overtone of Dzieci stamtad may be a challenge, since in certain places the saga reads like a 'tearjerker'. This characteristic is prominent, for instance, when Michelle - John's wife-to-be - receives from him, just before their wedding, an envelope containing the Polish soil he had managed to bring to Canada. And of course this soil, carried in an envelope (earlier in a small bag that he had to hide under his cap when he was crossing the Canadian border, for fear that he would be asked to give it away), is of great value to him. In a symbolic way, this is his 'portable' mother country, his Polishness that is so dear to him regardless of time and place. Michelle is so deeply moved by the gift that she kisses the envelope and places it on her heart. The novel is filled with similar passages that are slightly too sentimental but which, at the same time, are rendered very realistically.

It is clear that the meaning and importance of the tradition in which the Pawulskis were raised is one of the underlying themes in the whole story. As vital as it is, it will also have to stand the test of time (and place). John symbolically breaks away from it when he decides to change his name and surname from John Pawulski to Jean Aucoin. The way the Polish diaspora functioned in Canada in the 1940s and 1950s is also presented in the novel in a micro scale. George Pawulski starts cultivating Canadian land and John chooses a different path, though also quite 
traditional for Poles at the time - he turns to trade and works in Favreau's shop, which he is going to inherit in the future. Cousture has definitely done some research into the ways in which Polish people tried to establish their lives in Canada and into the economic sectors in which they most often operated, giving the reader a flavour of how things really were.

In the age of 'rampant' feminism, the way female characters have been portrayed by Cousture may be hard to enjoy, as they are very sentimental and over-emotional. On the other hand, we should bear in mind that in the last two decades of the $20^{\text {th }}$ century (the book was released in the 1990s), many books written by women and about women appeared on Québec's book market. This was connected with a new trend in Québécois literature. As noted by Mary Jean Green, “(...) contemporary women writers seek out traces of the past and use them as a point of departure for the reconstruction of women's lives. The new wave of women's historical fiction thus takes up the effort of presentation of women's history at the point where documentation fails, attempting to delve further into what French historian Jacques Le Goff called 'the archives of silence"' 4 Though Dzieci stamtąd is not classic historical fiction, it is hard to deny that it falls into a trend (a new trend in the last two decades of the $20^{\text {th }}$ century) of writing about women. Though they might seem obedient and submissive from the perspective of a $21^{\text {st }}$-century reader, they are very strong characters. Perhaps Cousture's women seem too emotional and sentimental, but I did not get the impression that they are passive characters who wilfully choose to remain in their husbands' shadows. I believe I owe this feeling to the author who has a great flair for creating vivid male and female characters.

I have come across an opinion that one of the book's strengths is its sense of humour. It is true, there are a few hilarious passages in the novel, even if sometimes unintentionally hilarious, like when we read a description of Ann's protruding tooth which in one place seems beautiful to her husband George, yet later "sticks out quite ugly". This becomes a recurrent symbol in the novel and, intentionally or not, has a humorous effect. Cousture's inclination for creating sentimental descriptions and dialogues is balanced in this work with her talent for composing truly poetic comparisons which reveal her female gentleness that can be sensed between the lines throughout the whole text. Dzieci stamtad reads smoothly and the reader is not inhibited by any kind of labyrinthine, modernist composition in which the author would presents the story from a nonlinear time perspective. There are no flashbacks, there is no foreshadowing, and the text is composed in the form of a mosaic. Each part is divided into smaller units and the episodes from characters' lives are presented interchangeably. In the book's very simple structure, one may even have the feeling that Cousture leaps too abruptly from one episode

${ }^{4}$ M. J. Green (2001), Women and Narrative Identity: Rewriting the Québec National Text, Montréal: McGill-Queen's University Press, p. 129. 
to another. But on the other hand, the reader is guided smoothly through this multi-layered narrative.

I read Dzieci stamtad in Polish, then checked if it had been translated into English, but to my surprise found that it had not. I must admit that the pleasure of reading the book has been considerably spoiled by its Polish translation. The sensitivity of the author, her gentle feminine touch with which she embraced the Pawulski family's story, unfortunately is not rendered well in Polish due to the much less sensitive 'ear for language' of the book's three translators. Interestingly enough, they remained uniform in terms of the literary style they have chosen for their parts, but there are still many clumsy, artificially sounding sentences in the book.

It is hard to determine how the novel will be received by Polish readers, but among the positive aspects of the Polish translation of the book it must be noted that thanks to the Bridge Foundation, the official patron of the "Stop the Culture of Waste" campaign, 2,000 copies of Dzieci stamtad were printed on eco-friendly paper and sent to libraries throughout Poland.

Sagas read well in Québec, time will show if Polish readers are equally enthusiastic about this genre, and if they look forward to the second volume of the book to be translated into Polish. 